\title{
PIRSTALEISUUDESTA SYNTEESIIN YMPÄRISTÖKOULUTUKSESSA
}

Julkisuudesta voisi päätellä, että ympäristökasvatuksessa ja koulutuksessa tapahtuu hyvin paljon ja merkittävää. Tämä on paljolti näköharha. Ympäristön pilaantuminen jatkuu vähintään samaa tahtia kuin ennenkin, mikä on dokumentoitu mm. "Ympäristön tila Suomessa" -raportissa (Toim. Erik Wahlström ym., Gaudeamus 1992) ja koko maapallon osalta esim. Worldwatch -instituutin raporteissa. Ihmisten tietoisuus ympäristöongelmista on kyllä lisääntynyt, mutta henkilökohtaiset uhraukset asian hyväksi eivät. Ympäristönsuojelu on oireiden hoitoa ja ympäristökoulutuksessakin keskitytään kirjoittajien mielestä vääriin asioihin. He vaativat radikaalia uudelleen orientoitumista.

\section{Lokeroitunut tiede on neuvoton}

Useimmissa kirjoituksissa arvostellaan voimakkaasti tiedeyhteisöä ja tieteen toimintatapoja. Sektoroitunut, lokeroitunut ja arvovapautta korostava tiede näyttää kyvyttömältä ympäristöongelmien ratkaisussa. Kulttuuriseen itsereflektioon ei kyetä, vaan pidetään länsimaista teollisuus- ja kulutusyhteiskuntaa parhaana mahdollisena ja tiedettä sen suurimpana ylpeyden aiheena. Ympäristöongelmat ja muutkin todella merkittävät ongelmat ovat niin monimutkaisia, että nykyisen tieteen kapeaalaiset spesialistit eivät saa niistä otetta.

Tehdäänpä ajatuskoe. Oletetaan, että joku ihminen haluaisi selvittää itselleen mistä ilmansuojelusta on kysymys. Hän luultavasti menee ilmansuojelukurssille. Opiskelee vuoden ilmakemiaa ja -fysiikkaa, erilaisten saasteiden vaikutuksia, lainsäädäntöä ja muita yhteiskunnallisia vaikuttamiskeinoja. Tämän jälkeenkin henkilön on pakko todeta, että hänen ymmärryksensä ilmansuojeluongelmien syistä ei ole lisääntynyt juuri ollenkaan. On keskitytty oireisiin ja niiden hoitoon eikä sairauden todellisiin syihin. Ilmansuojeluongelmien aiheuttajia eivät ole niinkään pöly, rikkidioksidi jne. vaan ihmisten kollektiivinen käyttäytyminen. Tämän ymmärtäminen puolestaan vaatisi syvällis-
Outi Kinttula ja Tarja Parviainen (Toim.) 1992: Ojasta allikkoon? Puheenvuoroja ympäristókoulutuksen itsestäänselvyyksistä. Suomen Ylioppilaskuntien liftto r.y. SYL-julkaisu 3/92

tä koko kulttuurin perusteiden pohdintaa. Kyseessä on koko yhteiskunnan sairaus. Siihen vastaaminen edellyttäisi opetuksen ja tutkimuksen muuttamista tavalla, joka ei nykyisissä puitteissa näytä mahdolliselta.

Voidaanko kaikki korkeakouluopiskelijat kouluttaa ympäristövastuuseen, pohtii Riitta Wablström. Tavoitteet ovat kovin idealistisia, eikä niiden toteuttaminen nykyisessä yliopistolaitoksessa näytä todennäköiseltä. Tämä käy hyvin myös ilmi kun tarkastellaan yksittäistä opetusalaa kuten Satu Hassin arvioimaa insinöörikoulutusta tai Risto Santin tarkastelemaa lääketiedettä. Koko teoksessa pidin eniten Satu Hassin virkistävän kriittisestä tarkastelusta ja selkeästä argumentaatiosta. Tutkintonsa nojalla hän arvosteli insinöörikoulutuksen kapea-alaisuutta. "Heidät koulutetaan maailman muuttajiksi, mutta heitä ei valmenneta pohtimaan sitä, mitä he maailmalle tekevät". Kirjoituksen pääsisältö on kuitenkin feministinen näkökulma yhteiskuntaan ja sen luontosuhteeseen. Ympäristöongelmat eivät ainakaan vielä paljon näy sairaustilastoissa. Sen vuoksi ympäristölääketiede on saanut kovin vähän harrastusta osakseen myöskin sen vuoksi, että se rikkoisi vakiintuneita oppituolien rajoja, toteaa Risto Santti.

\section{Postmoderni keinotodellisuus ja systeemin kahleet}

Tiedonvälityksen antamaa vääristynyttä kuvaa maailmasta pohtivat Timo Ala-Väbälä ja Jürgen Mattbies. Parhaiten perusteltu asiantuntijan näke- 
mys ei suinkaan saa eniten huomiota. Tiedotusvälineiden kautta yleiseen tietoisuuteen ja siten politiikkaa ohjaamaan suodattuvat näkemykset, jotka myötäilevät suuren yleisön ennakkoluuloja ja pelkoja. Me elämme yhä enemmän postmodernissa joukkotiedotuksen luomassa keinotodellisuudessa tai hypertodellisuudessa, joka semanttisesti peittää näkyvistämme aineellisen todellisuuden.

Koko kirjan painavimman tekstin on tuottanut Jürgen Matthies postmoderniin filosofiaan ja hyvin laajaan ja monipuoliseen lähdeaineistoon perustuen. Yhteiskunnan toiminnan sisäinen rationaalisuus määrää mahdollisten muutosten puitteet. Järjestelmä alistaa ja kahlitsee ihmisen.

Itselleni on alkanut hahmottua vielä pessimistisempi näkemys. Kulttuurin olennainen muuttuminen ei ehkä ole mahdollistakaan. Ne ovat kehityksensä alussa saaneet tietynlaisen perustan, joka ei ole muutettavissa. Siksi jokaisen kulttuurin, kuten lajinkin osana on aikanaan tuhoutua. Näin on käynyt kaikille aikaisemmille korkeakulttuureille. Miksi nykyinen muodostaisi poikkeuksen. Erona on vain se, että nykyinen kulttuuri on ensimmäinen, joka voi omasta tahdostaan olla myös viimeinen.

Matthies osoittaa vastaansanomattomin esimerkein, miten ympäristönsuojelutoimet samoin kuin toteutettu ympäristökasvatus ovat paljolti terapiaa, jotta voisimme sietää ristiriitaa jatkaessamme entisenlaista elämäntapaamme ja kulutustamme.

\section{Missä on kriittinen ekologinen kulttuuriteoria?}

Tämä pieni kirja on erittäin tervetullut kriittinen kannanotto ympäristökeskusteluun. Se on selkeästi oppositiossa ympäristökoulutuksen valtavirtaa vastaan. Mielestäni oppositio on oikeassa. Heidän kritiikkinsä on oikea, mutta heillä ei ole antaa ratkaisua tilalle. Tarvitaan kriittistä ekologista kulttuuriteoriaa, kuten Jürgen Matthies asian ilmaisi. Missään ei kuitenkaan ole näkynyt vakavasti otettavaa yritystä yhdistää luonnontieteellinen, yhteiskuntatieteellinen ja humanistinen näkökulma samaan teoriaan. Tieteistä ehkä kulttuuriantropologialla voisi olla parhaat edellytykset tällaisen synteesin tekemiseen. Valitettavasti antropologit ovat kuluttaneet kenttätyöaikansa etenkin tropiikin alkuperäiskansojen parissa. Modernin teollisuusyhteiskunnan monimutkaisuuden edessä tutkijoiden sisu sen sijaan on yleensä noussut kaulaan. Oman kulttuurin arviointi on kaikkein vaikeinta. Nyt jos koskaan kaivattaisiin rohkeita synteesin tekijöitä. 